\title{
Mammal fauna of Ihlara Valley (Aksaray, Turkey)
}

\author{
Kubilay Toyran a,*, Tarkan Yorulmaz ${ }^{\mathrm{b}}$, Serdar Gözütok ${ }^{\mathrm{c}}$ \\ a Bitlis Eren University, Faculty of Science and Arts, Department of Biology, Bitlis, Turkey \\ b Çankırı Karatekin University, Faculty of Science, Department of Biology, Çankırı, Turkey \\ c Abant İzzet Baysal Universty, Faculty of Agriculture and Natural Sciences, Department of Wildlife and Ecology, Bolu, Turkey
}

\section{Article history:} \\ 2017 \\ Keywords: \\ Mammal species \\ Distribution \\ Ihlara Valley \\ Turkey
}

A R T I C LE IN F O

Received 16 November 2017

Received in revised form 28 November

Accepted 29 November 2017

\begin{abstract}
A B S T R A C T
This study was conducted between 2010 and 2011. The goal of study is to identify mammal species in the area and determine factors threatening these species. As a result of field studies, totally 20 species were identified from the orders Eulipotyphla, Chiroptera, Lagomorpha, Rodentia, Carnivora, and Artiodactyla of Mammal class. Factors that threaten mammal species and protective measures were given.
\end{abstract}

(C) 2017. Turkish Journal Park Academic. All rights reserved.

\section{Introduction}

Turkey is considerably rich in elements of fauna and flora due to its geographical location. Ecological, geological, and climatic differences of the country play an important role in formation of biological diversity. Today, more than 160 species of the orders Insectivora (Eulipotyphla), Bats (Chiroptera), Hares (Lagomorpha), Rodents (Rodentia), Sea mammals (Cetacea), carnivors (Carnivora), Pinniped (Pinnipedia), Odd-toed Ungulate (Perissodactyla) and Eventoed Ungulate (Artiodactyla) of Mammal class exist in Turkey (Toyran, 2011).

Ihlara valley has climatic and geographical structure which is substantially different from characteristics of Central Anatolian Region where it is located. There are numerous structures which could be shelter for mammal species within the valley due to intensive human activities in the previous periods. Melendiz Stream which is located within the valley is also substantially important for living organisms. The valley being about $14 \mathrm{~km}$ long also has a microclimate property due to its position. When considering these characteristics, it is important to identify mammal species in the valley and to determine the activities threatening these species.

\section{Material and Methods}

Field studies were conducted within different seasons (spring, summer, fall, winter) in 2010-2011 to identify mammal species inside the Ihlara Valley located in Ihlara Town of Güzelyurt district of Aksaray province (Figure 1). The valley was divided into three regions by considering entrances with counter and iron fence (Figure 2). Samples representing the mammal species were obtained using traps for catching alive, insect nets, and net. Identification of species was carried out in the field and they were released in to their habitats again. The species which are hard to catch and monitor were observed via binoculars. Some species were identified indirectly from footprints and feces. Photos of mammal samples, their nests, and habitats were recorded with camera

\footnotetext{
* Corresponding author.

Tel.: +0 5063667339

E-mail address: kubilaytoyran@hotmail.com
} 
and photographic apparatus. Species were given according to taxonomic order.

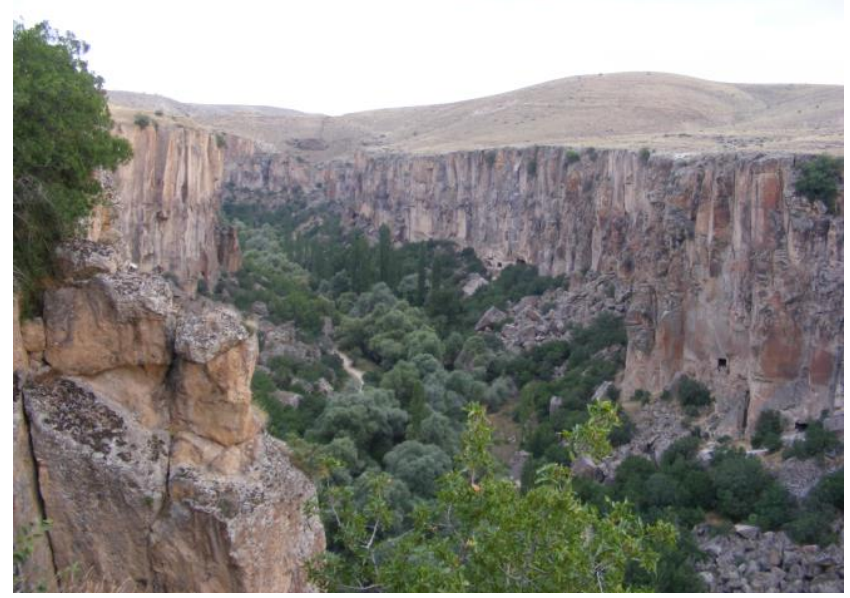

Figure 1. A view from the valley

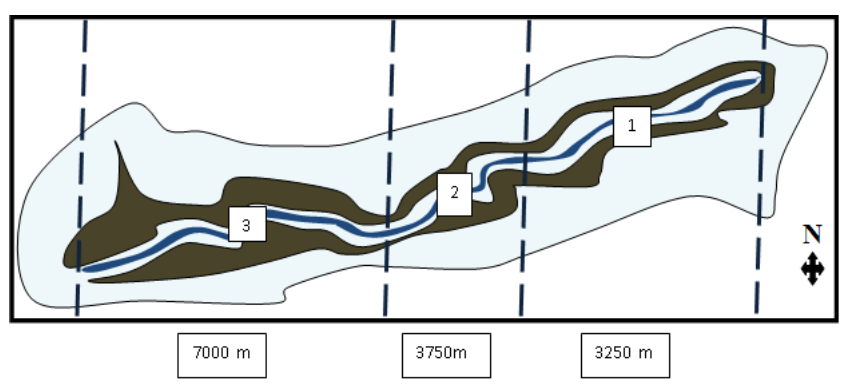

Figure 2. Ihlara Valley research areas (1: Ihlara region i; 2: IhlaraBelisırma region; 3: Belisırma-Selime region)

\section{Results and Discussion}

As a result of field studies, totally 20 species were identified from the orders Eulipotyphla, Chiroptera, Lagomorpha, Rodentia, Carnivora and Artiodactyla of Mammal class.

\section{Order: Eulipotyphla}

There are 17 species from the order Eulipotyphla in Turkey (Kurtonur et al., 1996). Existence of one species from each of families Erinaceidae and Soricidae was identified in Ihlara Valley and its surrounding region.

\section{Erinaceus concolor Martin, 1837}

The members of this species were detected in borders of fields on the edges of roads close to the valley (Figure 3).

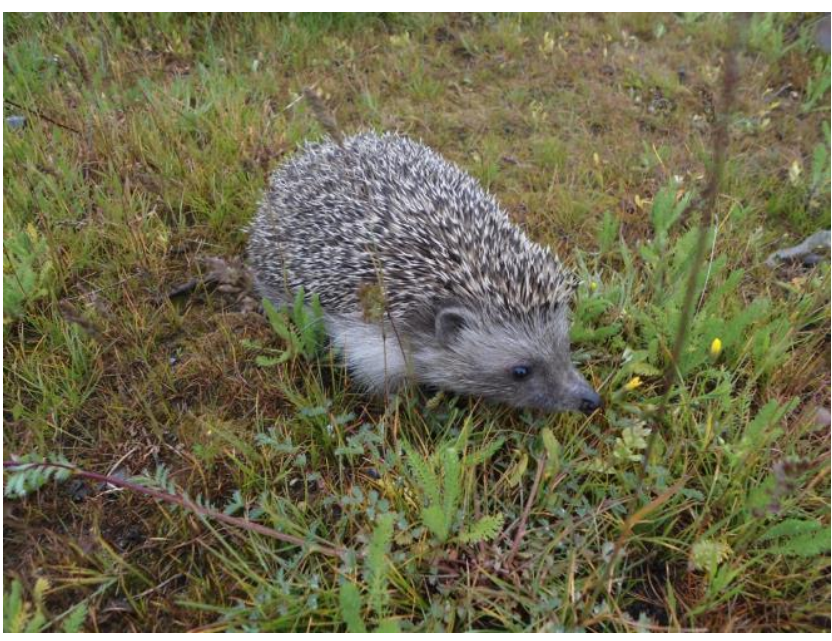

Figure 3. Erinaceus concolor

\section{Crocidura suaveolens (Pallas, 1811)}

This species was identified in grassland and bush in the shore of Melendiz Stream in the study field (Figure 4).

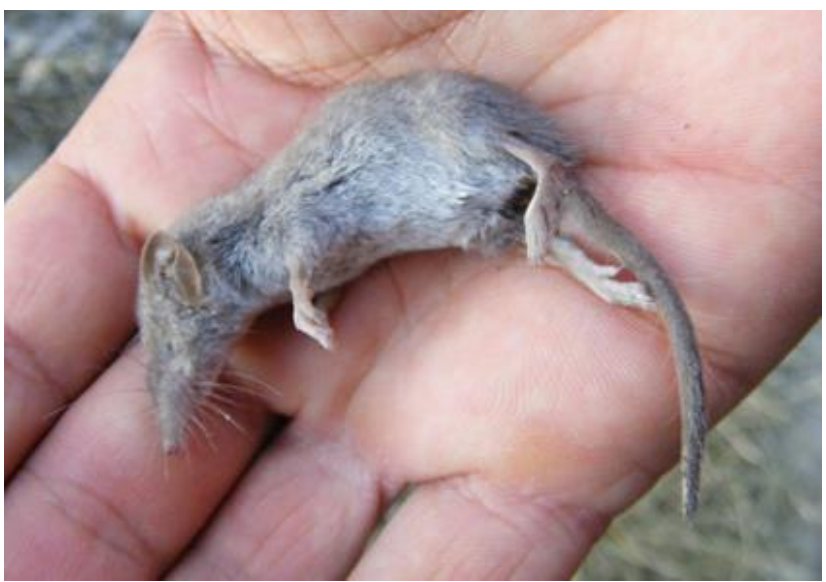

Figure 4. Crocidura suaveolens

\section{Order: Chiroptera}

39 bat species from the order Chiroptera, one of which feeds with fruits and 38 of which feed with insects, are living in Turkey (Yorulmaz and Arslan, 2016). 6 bat species from families Rhinolophidae and Vespertilionidae were identified in Ihlara Valley.

\section{Rhinolophus ferrumequinum (Schreber, 1774)}

This species was identified in artificial caves which had been used as church and shelter in previous ages within Ihlara Valley (Figure 5). 


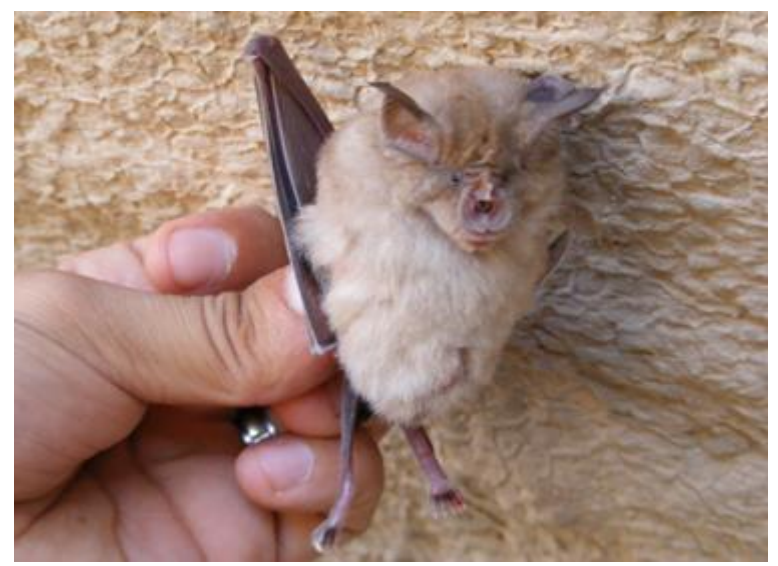

Figure 5. Rhinolophus ferrumequinum

\section{Rhinolophus hipposideros (Bechstein, 1800)}

This species was identified in artificial caves which had been used as church and shelter in previous ages within Ihlara Valley (Figure 6).

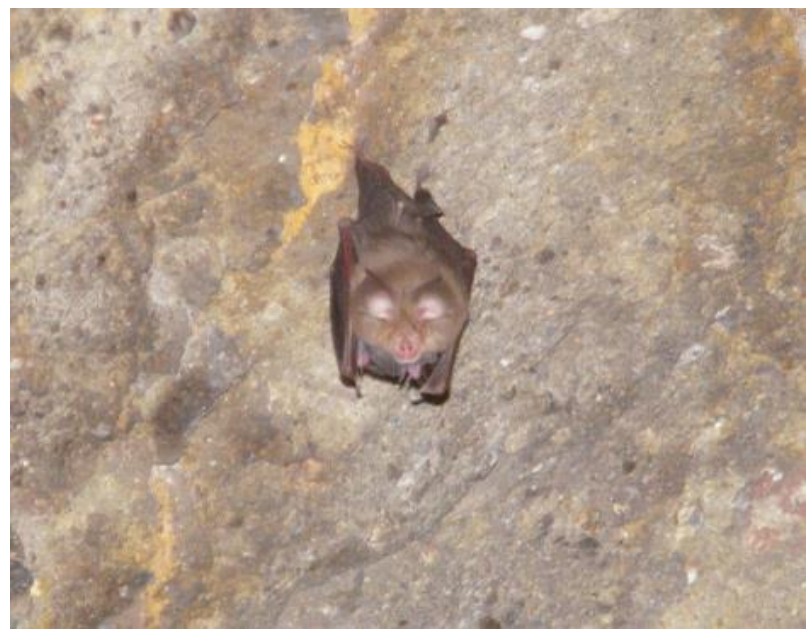

Figure 6. Rhinolophus hipposideros

\section{Myotis mystacinus (Kuhl, 1819)}

It generally lives inside places such as small caves, castle wall, roof spaces, and tree holes. In Ihlara Valley, this species was identified by being caught with the aid of a net which was stretched on Melendiz Stream at night (Figure 7).

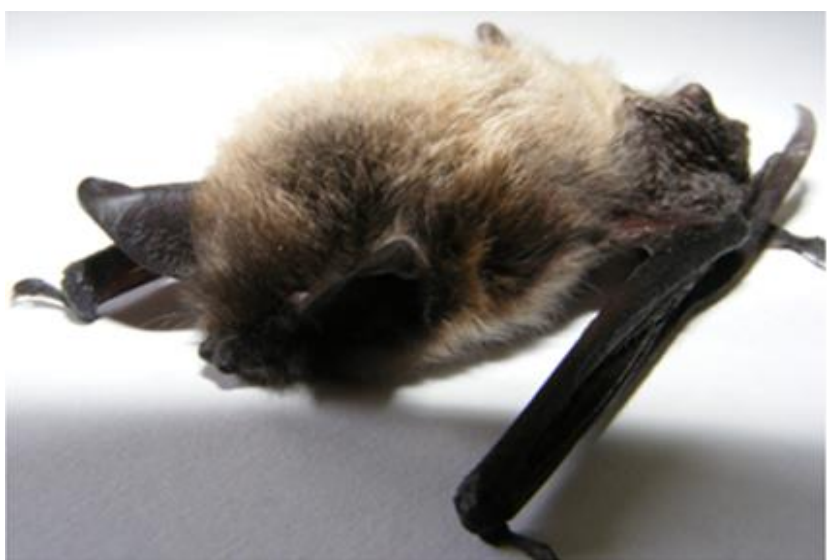

Figure 7. Myotis mystacinus

\section{Myotis emarginatus (Geoffroy, 1806)}

It was identified to be hanging solitarily on the ceiling of a cave which had been previously used as shelter (Figure 8).

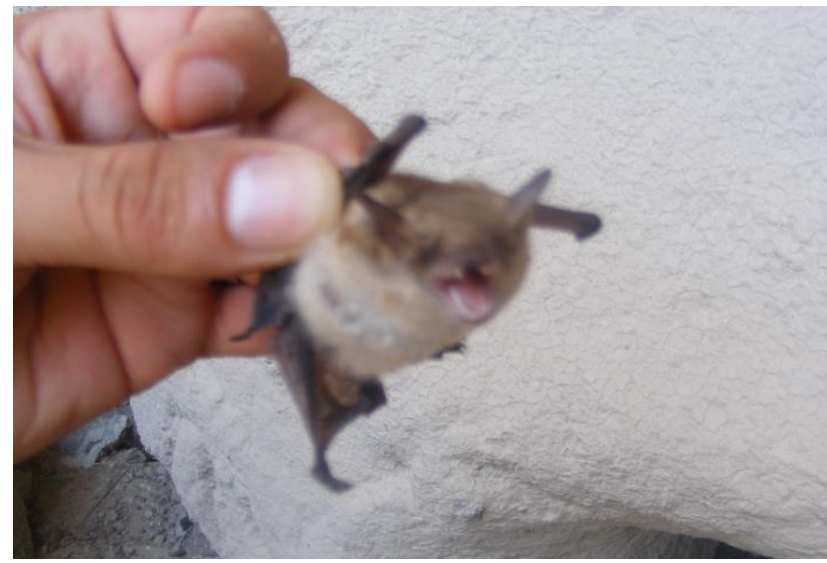

Figure 8. Myotis emarginatus

\section{Myotis myotis (Borkhausen, 1797)}

It was identified in a crack on the ceiling of a multiple stairs cave which had been used as shelter (Figure 9).

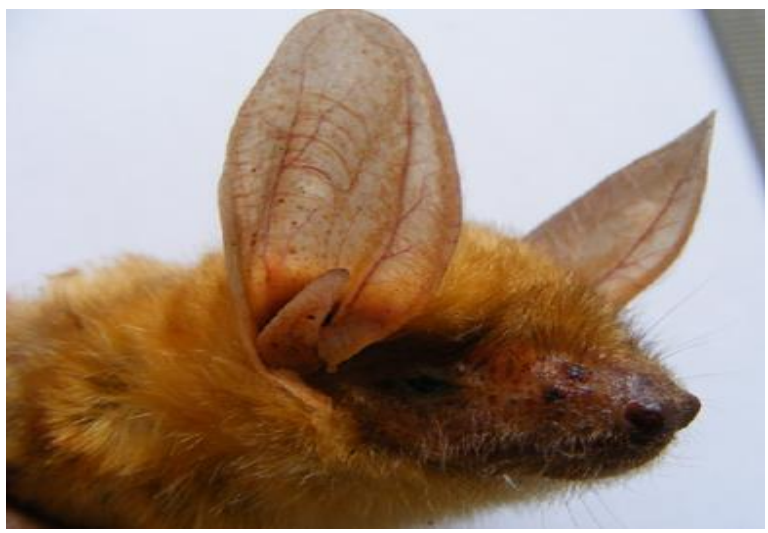

Figure 9. Myotis myotis 


\section{Plecotus auritus (Linnaeus, 1758)}

This species was identified in the entrance of an artificial cave with multiple sections which had been used as shelter (Figure 10).
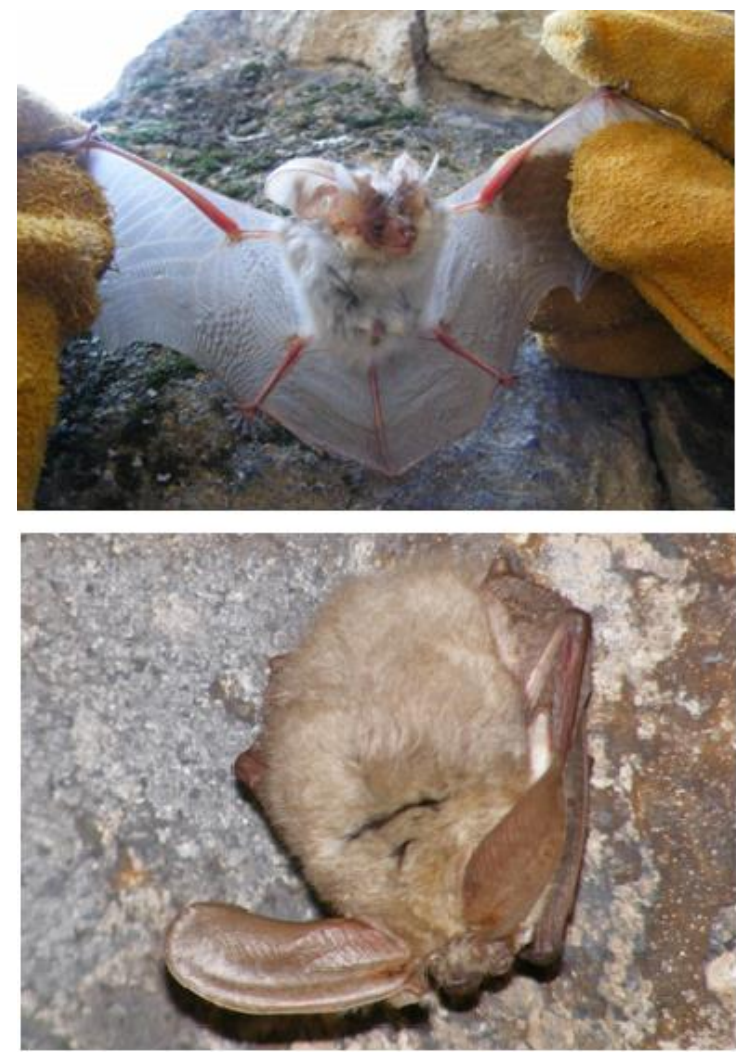

Figure 10. Plecotus auritus

\section{Order: Lagomorpha}

Single species from the order Lagomorpha is known from Turkey (Demirbaș and Albayrak, 2014).

\section{Lepus europaeus Pallas, 1778}

This species was identified in the plains around the valley and areas where the bottom of the valley enlarged (Figure 11).

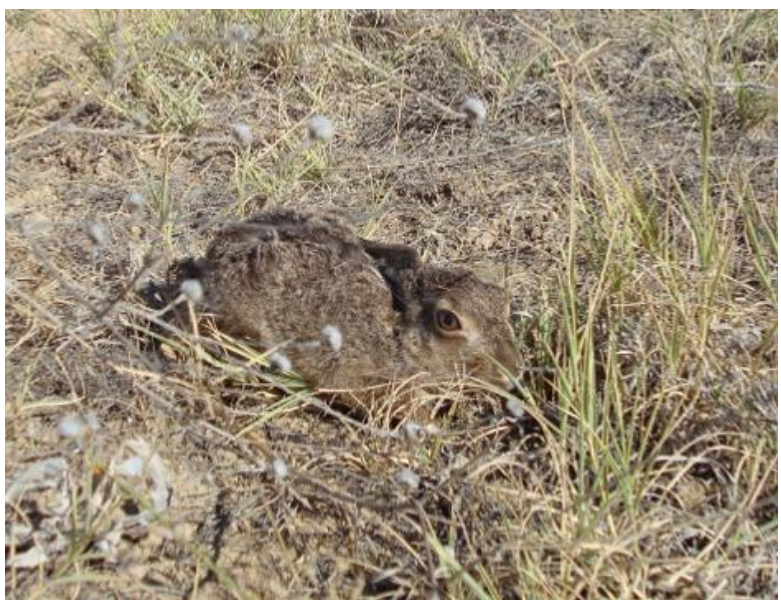

Figure 11. Lepus europaeus

\section{Order: Rodentia}

A total of 67 species from the order Rodentia are known from Turkey (Yiğit et al., 2006). Field studies revealed that 7 species from the genera Spermophilus, Arvicola, Microtus, Nannospalax, Apodemus and Allactaga spread in the region.

\section{Spermophilus xanthoprymnus (Bennett, 1835)}

This species was detected in plain areas around the valley and in a region used as football field in the bank of Melendiz Stream in Belisırma locality (Figure 12).

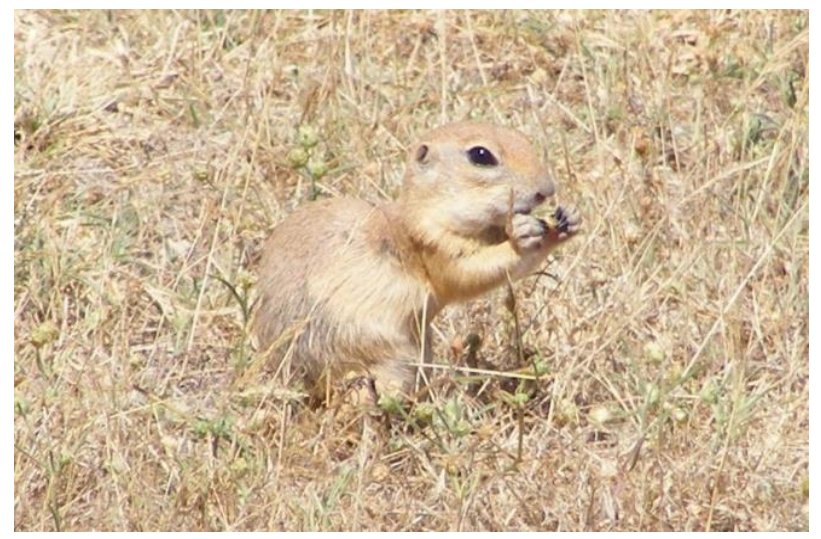

Figure 12. Spermophilus xanthoprymnus

\section{Arvicola amphibius (Linnaeus, 1758)}

This species was identified in shrubbery located in the bank of Melendiz Stream within the valley (Figure 13). 


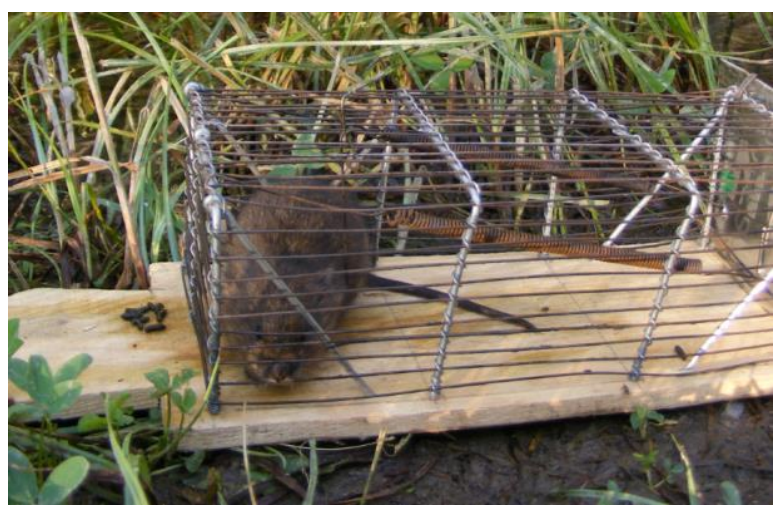

Figure 13. Arvicola amphibius

\section{Microtus guentheri (Danford and Alston, 1880)}

This species was identified in both garden-like plane areas in the bottom of the valley and fields and plains out of the valley (Figure 14).

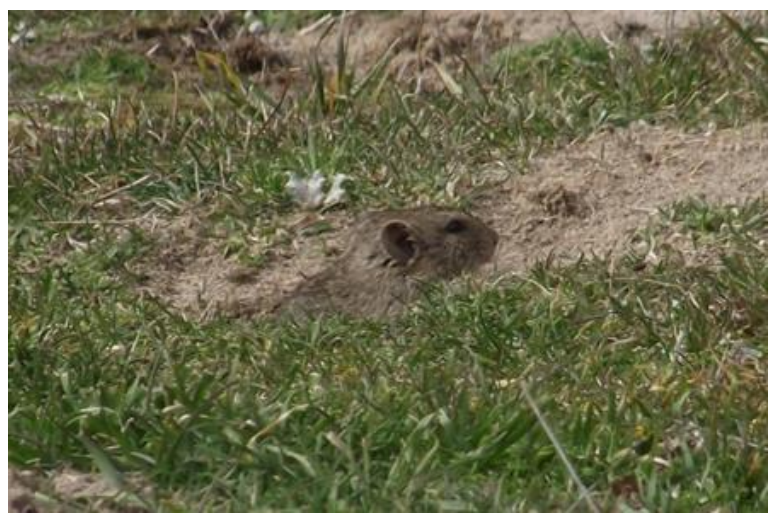

Figure 14. Microtus guentheri

\section{Nannospalax xanthodon (Nordmann, 1840)}

This species was detected in plane areas within the valley and fields out of the valley (Figure 15).

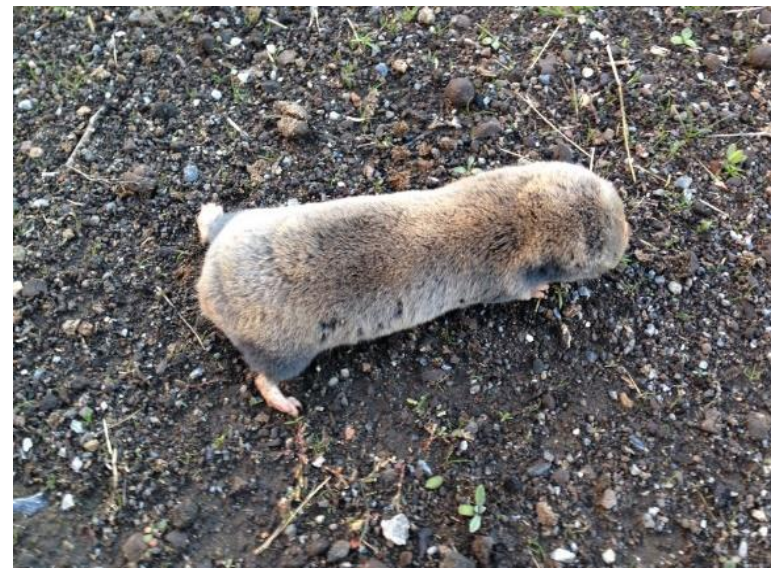

Figure 15. Nannospalax xanthodon

\section{Apodemus mystacinus (Danford and Alston, 1877)}

This species was identified in rocky areas in the valley (Figure 16).

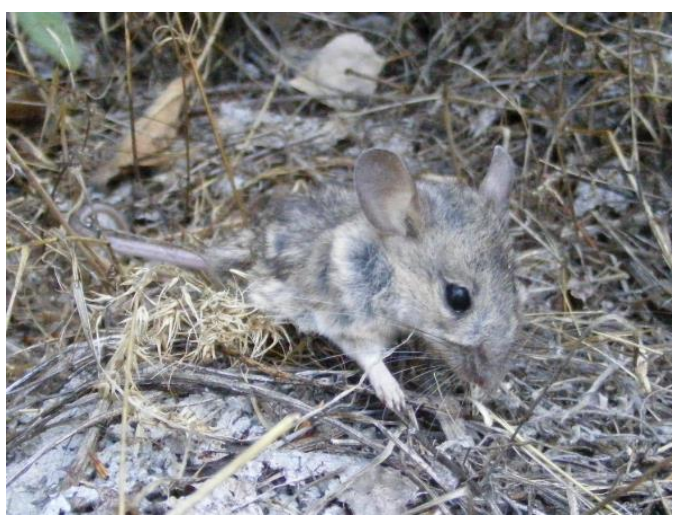

Figure 16. Apodemus mystacinus

Apodemus witherbyi (Thomas, 1902)

This species was detected in shrubbery and woodlands by the Melendiz Stream in the study field (Figure 17).

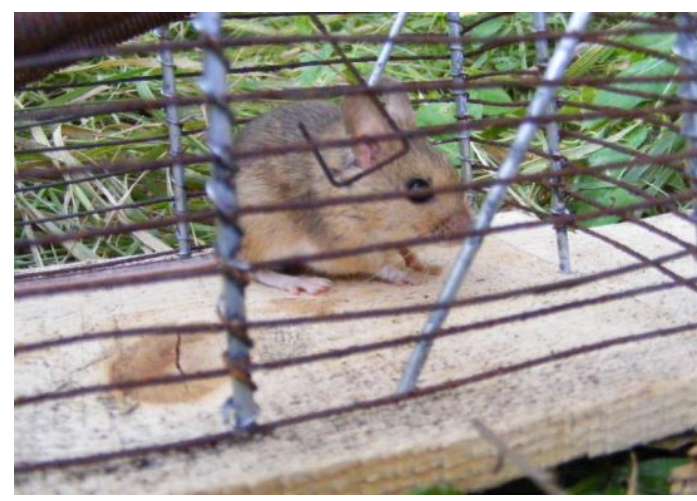

Figure 17. Apodemus witherbyi

\section{Allactaga williamsi (Thomas, 1897)}

This species was identified in non-agricultural areas with sparse herbaceous vegetation out of the valley (Figure 18).

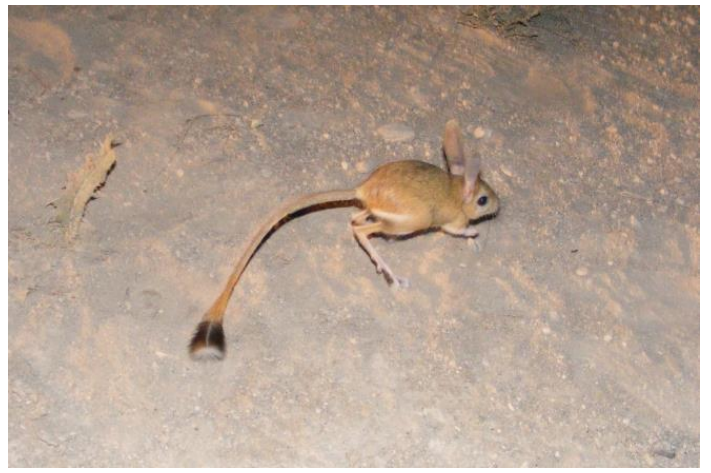

Figure 18. Allactaga williamsi 


\section{Order: Carnivora}

19 species from the families Canidae, Ursidae, Mustelidae, Viverridae, Hyaenidae and Felidae of the order Carnivora are distributed in Turkey (Albayrak et al., 1997; Toyran, 2016). One species from each of the genera Vulpes, Martes and Meles were identified in Ihlara Valley and its surrounding area.

\section{Vulpes vulpes (Linnaeus, 1758)}

This species was identified both within the valley and areas on the slopes of the valley. Two individuals died due to starvation after falling in to a hole in a cave were identified during field studies and another one which was shot inside a garden around Belisırma locality (Figure 19).

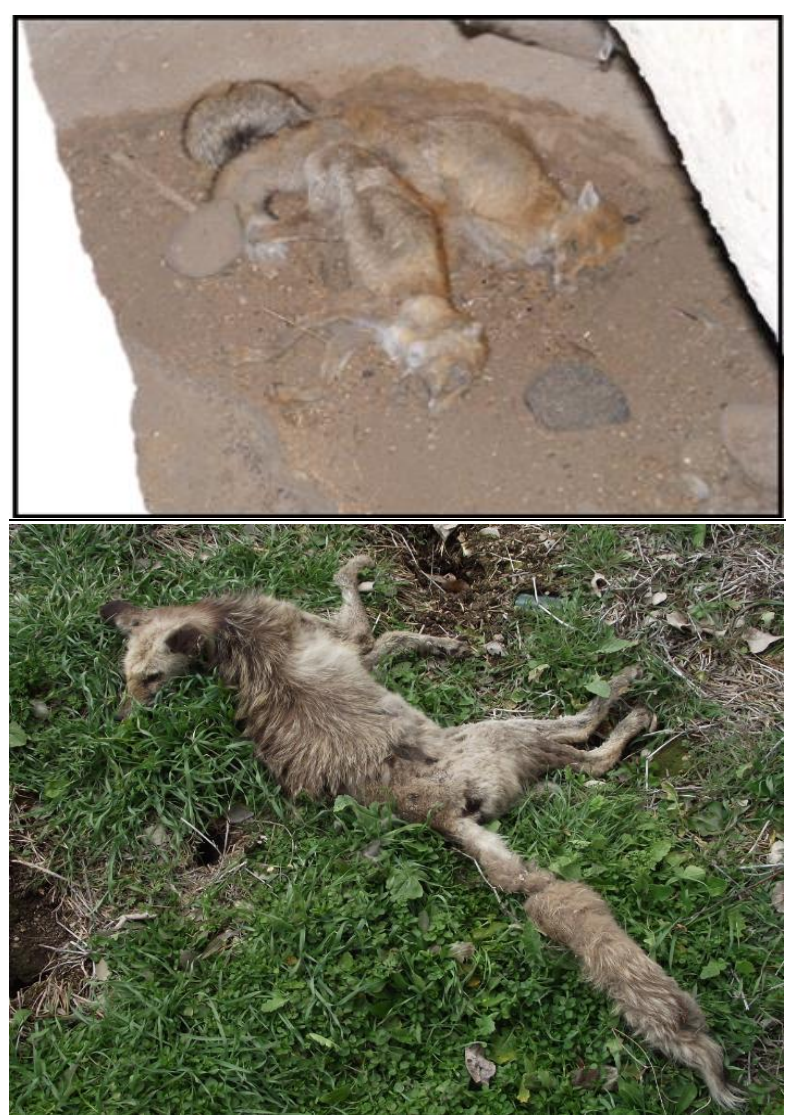

Figure 19. Vulpes vulpes

\section{Martes foina (Erxleben, 1777)}

The presence of this species in the area was determined indirectly from fecal residues of the species (Figure 20).

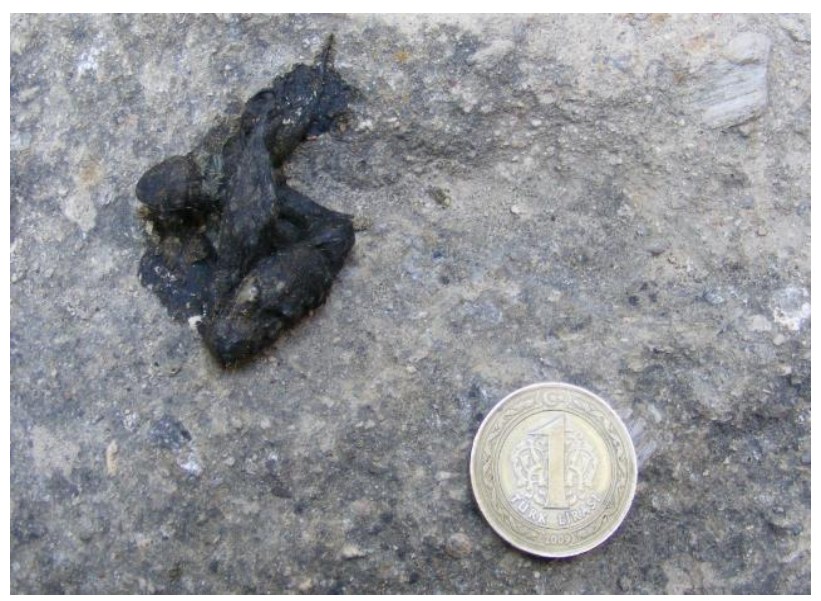

Figure 20. Feces sample of Martes foina

\section{Meles meles (Linnaeus, 1758)}

The existence of this species in the area was indirectly identified from footprints of the species (Figure 21).

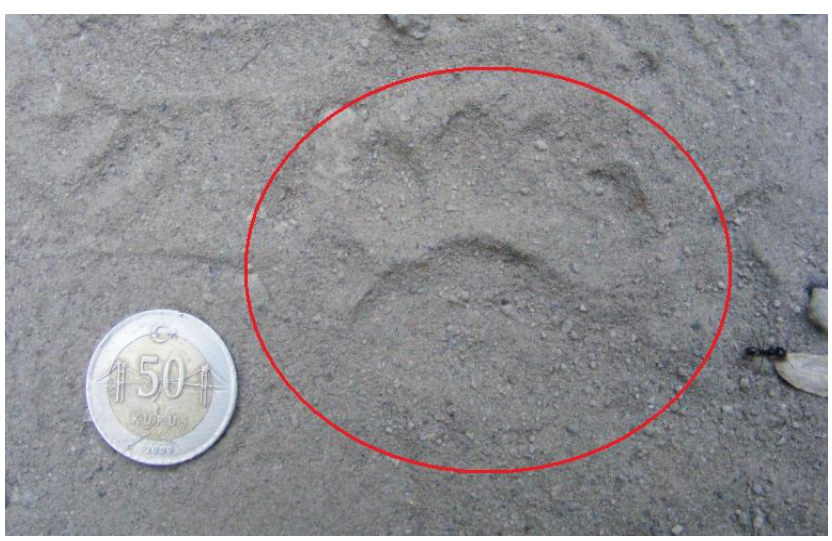

Figure 21. Footprint of Meles meles

\section{Order: Artiodactyla}

The order Artiodactyla is represented by 13 species in Turkey (Albayrak et al., 2007). One species from the genus Sus in the family Suidae was identified in the present study.

\section{Sus scrofa Linnaeus, 1758}

The presence of this species in the area was identified indirectly from grubbing traces of the species (Figure 22). 


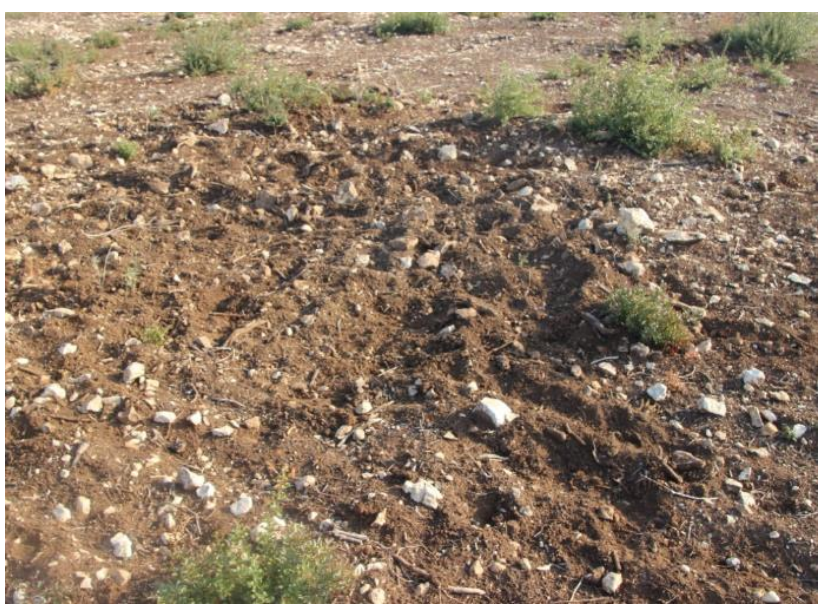

Figure 22. Digging trail of Sus scrofa

The field of the study is a valley like a canyon and has microclimate characteristics. While more than 160 mammals species are known from Turkey (Toyran, 2011), the number of species identified from the valley is 20 in this study. In this case, it can be asserted that the valley has rich mammal diversity. It is very important in terms of tourism for the region to have a historical past. It holds an important potential of domestic and foreign tourists. Therefore, this situation may constitute some threats for the mammal species identified in the area.

We can list the threats in the area as follows;

a) Restricted geographical structure of the area makes the species living here dependently more vulnerable in front of any kind of danger.

b) Continuous visits to caves negatively influence the bat species existing around here.

c) Human mobility is felt very closely by animals because it is a limited and narrow area. Unconscious behaviors of people, who do not have enough knowledge about the biological diversity of the area and characteristics of existing species, in the region influence animals negatively.

d) Any pollution that may occur in the stream located in the bottom of valley, decrease of water flow by facilities or destruction of water course will negatively affect biological diversity of the area.

We can list the solution suggestions to be taken for threats in the area as follows;

a) It should be prevented to establish facilities that will threat wild life around the valley. Protection borders of the area should be extended further.

b) Tourism activities carried out in the area for bat species need to be limited in some caves in critical periods. Visits to caves should be controlled depending on the presence of bats, caves where bats may shelter should be closed to visits. c) Local people should be informed about biological diversity of the area, characteristics of existing species, and their protection status. Signboards about species should be placed in various spots of the valley.

d) The quality of the stream in the area should be ensured to be sustainable. Any facility layout or destruction should not be allowed.

\section{Acknowledgements}

The present study was conducted with the permission of T.R. Ministry of Environment and Urban Planning, Directorate General for Preservation of Natural Heritage under the title of "The Project for Identification of Biological Diversity in Special Environmental Protection Area of Ihlara and contributions of Çınar Mühendislik Müşavirlik A.Ş.".

\section{References}

Albayrak, İ., Pamukoğlu, and N., Așan, N., 1997. Bibliography of Turkish Carnivores (Mammalia: Carnivore). Communication Fas. des. Scien. de L univ. d-Ankara. Series C, 15, 1-20.

Albayrak, İ., Pamukoğlu, N., and Kaya, M.A., 2007. Bibliography of Turkish eventoed Ungulates (Mammalia: Artiodactyla). Munis Entomology \& Zoology, 2, 143-162.

Demirbaș, Y., and Albayrak, İ., 2014. The taxonomic status and geographic distribution of the European hare (Lepus europaeus Pallas, 1778) in Turkey (Mammalia: Lagomorpha). Turk J Zool., 38, 119-130.

Kurtonur, C., Albayrak, İ., Kıvanç, E., Kefelioğlu, H., and Özkan, B., 1996. Türkiye Omurgalılar Tür Listesi; Memeliler (Mammalia). DPT/TBAG- Çev. Sek., Nurol Matbaası (in Turkish).

Toyran, K., 2011. Memeli Hayvanlar (Mammalia). 483-524, İçinde: Gaziantep'in Biyolojik Çeşitliliği (Özuslu, E., Tel, A.Z., eds), Doğa Koruma Derneği Yayınları (in Turkish).

Toyran, K., 2016. Predatory Mammal Species of Bitlis Province (Mammalia: Carnivora). Iğdır Univ. J. Inst. Sci. \& Tech., 6, 27-32.

Yiğit, N., Çolak, E., Sözen, M., and Karataş, A., 2006. Rodents of Türkiye (Türkiye Kemiricileri). Meteksan.

Yorulmaz, T., and Arslan, N., 2016. Türkiye Yarasalarının (Mammalia: Chiroptera) Son Durumu ve Ulusal Korunma Statüleri İçin Öneriler (Poster Sunum). 23. Ulusal Biyoloji Kongresi, 5-9 Eylül 2016, Gaziantep (in Turkish). 